NBER WORKING PAPER SERIES

\title{
PUBLIC POLICY AND EMPLOYMENT DISCRIMINATION IN THE U.S.
}

Richard B. Freeman

Working Paper No. 928

\author{
NATIONAL BUREAU OF ECONOMIC RESEARCH \\ 1050 Massachusetts Avenue \\ Cambridge MA 02138
}

$$
\text { July } 1982
$$

\footnotetext{
Prepared for the Anglo-American Seminar on Ethnic Minorities and Public Policy, Middle Aston House, Oxfordshire, May 1982. The research reported here is part of the NBER's research program in Labor Studies. Any opinions expressed are those of the author and not those of the National Bureau of Economic Research.
} 
NBER Working Paper \# 928

Ju1y 1982

Public Policy and Employment

Discrimination in the U.S.

\section{ABSTRACT}

This paper examines evidence on employment practices in the U.S. with respect to race and the impact of governmental anti-bias activity on these practices. It shows a striking difference in the responses of American employers to job applications differing in race from the responses of British employers and asks whether these differences can be attributed to the greater U.S. effort to aid minority workers. It reviews the recent research by Jonathan Leonard on the effect of court suits and affirmative action compliance activity and concludes that much of the improved status of minorities in the U.S. is indeed due to governmental activity and public po1icy.

Richard B. Freeman National Bureau of Economic Research 1050 Massachusetts Avenue Cambridge, MA 02138

(617) $868-3915$ 
Public Policy and Employment Discrimination in the U.S.

An employer is said to discriminate against workers of a given ethnic group when, faced with equally competent applicants for a job (pramotion) from that group and other groups, he selects members of the given ethnicity in disproportionately low numbers. If relatively many employers have such discriminatory attitudes members of the group discriminated against will be forced to take lower wages (worse jobs) than their peers or to suffer from unemployment. Their lower wages/worse jobs can be viewed as a means of compensating employers for prejudiced attitudes in the context of the theory of compensating differentials. $1 /$ In light of the preceding definition of employer discrimination, consider the comparative evidence on the ethnicity of successful job applicants in the U.S. and U.K. in the late 1970s displayed in Table 1. The figures in this table are taken from two roughly comparable U.S. and U.K. studies in which firms were mailed bogus applications of persons with equivalent credentials but differing ethnicity, and the treatment of the applications compared. While there are some differences between the studies (the U.S. study sent blind letters to finms from master lists of the office of Federal Contract Compliance (OFCC); whereas the U.K. study sent letters in response to job advertisements in the press), the basic procedures were the same. 2/ As is readily apparent in the table the results are not. The U.S. study found no evidence of discrimination against the "bogus" black job applications, and indeed the ensuing debate in the journal focused on the possibility of reverse discrimination; ${ }^{3 /}$ in the U.K. study, by contrast, there is remarkable differentiation in the success of applications among ethnic groups. While we lack a comparable U.S. study for an earlier period of time, or for companies who are not federal contractors and thus not required to take "affirmative action" in favor of minorities and women workers in addition to being subject to antibias employment laws, it is highly unlikely 
TABLE 1

\section{Percentage of Bogus Job Applications}

That are Successful U.S. vs. U.K.

responses

to

advertisement

U.K.

Nationality

Great Britain

Australia

France

Africa

India, Pakistan

West Indies
1977-78

85

75

68

53

44

48 blind letters to employers

U.S.

Ethnic

1977

30

24

Source: U.K.; Firth, Michael. Racial Discrimination in the British Labor Market," Industrial and Labor Relations Review Vol. 34, No. 2 (January 1981): 265-72; Table 1, p. 268.

U.S.; Newman, Jerry M. "Discrimination in Recruitment: An Empirical Analysis," Industrial and Labor Relations Review Vol. 32, No. I (October 1978): 15-23; Table 1, p. 20. 
that the U.S. firms showed the same color-blindness in treatment of applicants thirty or forty years ago," and may indeed have looked more like their British peers.

To what extent is the absence of employer discrimination among U.S. firms with federal contracts, at least at the level of responding to applicant letters, mirrored in aggregate statistics on incomes/occupational attainment by ethnic group? How great has been the improvement in the economic position of blacks, the major discriminated-against minority in the U.S.? To what extent can the evidence of nondiscrimination in Table 1 and changing patterns of aggregate labor market position be attributed to U.S. public policy? In light of the wide array of laws and policies in the U.S., what if anything can be said about the effectiveness of specific public policy tools?

\section{Aggregate labor market performance}

Table 2 presents a capsule summary of the change in the earnings, income, and occupational position of black workers over the entire postwar period, with the years 1964 (when Title VII of the Civil Rights Act of 1964, which made illegal employment discrimination, was passed in Congress); 1969, a "peak" economic year, and the most recent year for which I could obtain data included. The final column of the table records changes in the relevant ratios from 1964 (or closest year) to the most recent year.

The table tells a clear story. Virtually every indicator of positions shows a marked improvement in the economic status of employed black workers, with -- as has been widely noted by various analysts -- gains concentrated . among women, highly educated or skilled men, and young men. virtually every indicator of positions also shows a marked acceleration in the economic status of employed black workers after 1964, when the U.S. antibias effort intensified as a result of Title VII of the Civil Rights Act of that year. Despite the 
TABLE 2

Evidence on Black Earnings or

Incoue Progress in the 1970s

\section{Males}

1949

1964

$\underline{1969}$

1979

Change

1. Median Wages

and Salaries

All workers

. .50

. .59

.67

. .32

Year-round and

full-time workers

.66

.69

.76

2. Median or

usual weekly earnings

.69

(1967)

.71

.78

3. Median Income, by

Age, All Workers (1949)

and year-round full-time

workers (other years) 1949

$\underline{1959}$

1969

1979

Change

$\underline{1959-79}$

20-24

.66

.64

.82

.80

.16

25-34

.60

.61

.72

.80

.19

$35-44$

.55

.59

.68

.85

.26

45-54

.54

.55

.68

.67

.12

4. Median Income

or Mean Earnings,

by Years of

Education

1949

1959

1969

$\underline{1979}$

Change

1959-79

High school graduates

.68

.69

.68

.73

.04

College graduates

four years or more

.60

.60

.63

.76

.16

5. Ratio of Percen-

tage of all nonwhites criployed in occupations to percentage of 111 whiles in occupations 1950

1964

1969

1979

Change

Professionals

.45

.48

.54

1964-79

Managers

.22

.28

.37

.09

Craftsmen

.41

.58

.68

.81

.15

Manasers, college

Er adustes only 
TAB BI.E 1 (cont.)

$\frac{\text { Females }}{6 . \text { Median wages }}$
and salaries

All workers

Year-round and

full-t1me workers $\therefore$

7. Median usual weekly earnings

8. Ratio of percentage of all nonwhites in occupations to percentage of all whites in occupations $\underline{1950}$ 1964

Professiunals .47 .15
1964

1969

1979

Change

1964-79

.58

.79

1.02

.44

.82

.94

.25

(1955)

.69

.80

.83

.95

.15 1969

.83$$
.95
$$

1979

Change

1964-79

.60

.70

.75

.15

.33

.55

.79

Source:

Lines 1, 3, 4, 6: U.S. Bureau of the Census, as listed below. Lines $1 \& 6$ take the ratio of black and other race's earnings to whites. Lines $3 \& 4$, the same in 1969 and 1979. Lines $3 \& 4$ the ratio of blacks to all other workers in 1949 and 1959.

1949: Census of Population 1950; Special Reports: Education, Table 13.

1959: Census of Population 1960; Subject Reports: Educational Attainment, Table 6.

1964: Current Population Reports, Consumer Income Series P-60, No. 47, Table 33.

1969: P-60, No. 75, Tables $45 \& 59$ (1ines 1,3,6) and Table 47.

1979: Series P-60, No. 129, Tables $51 \& 62$.

Lines 2 \& 7: Monthly Labor Review, various issues. 1979 figure is for 1978.

Lines $5 \& 8$ : U.S. Bureau of Labor Statistics, Educational Attainment of Workers, Special Labor Force Reports No. 240, Table K, P. A-21; No. 125, Table J, p. A-29; No. 53, Table J, p. A-14. 1950 employment from Census of Population 1950, Education P-E No. 5B, Table 11, pp. 88-94 (figures for 15 and over).

a) College graduates four years only in 1959. 
poor performance of the econamy of the 1970s, there is no evidence of a decline in the relative black positions in that period. The continued positive trend in the face of cyclic forces operating against blacks $5 /$ suggests that the earnings and occupational progress of the post-1964 era are persistent rather than transitory developments. Detailed analyses of the changing patterns of progress of individuals and cohorts confirm this conclusion. 6/

The time pattern of the upswing in the labor market position of black Americans is analyzed in greater detail in Table 3, which examines whether or not there is, other factors held fixed, a time series relation between the post-1964 improvement in the relative economic position of blacks and the upswing of antibias activity in the period. The dependent variables, measured in logarithmic form, are: the median wage and salary earnings of nonwhite workers relative to white workers from 1947 to 1975; the median wage and salary earnings of nonwhite workers employed full-time year-round to the earnings of comparable white workers from 1955 to 1975; the ratio of the fixed weight index of the occupational position of nonwhite workers to the index for white workers from 1958 to 1975.

The explanatory variables are:

TREND, a time trend which takes the value 1 in the first year of the regression and increases by on unit in each succeeding year. This variable is designed to control for overall trends in the relative earnings of nonwhites.

CYCLE, a business cycle indicator which is obtained as the deviation of the log of real gross national product from its trend level.

EEO, real cumulated expenditures by the equal employment opportunity agency per nonwhite worker, measured in log units, with the value 1 used for the period prior to the Civil Rights Act of 1964 and as cumulated real spending per nonwhite plus 1 in later periods. This variable is 
essentially a post-1964 trend variable, which has the value 0 until 1965 , when the Act became effective and which trends upward thereafter. It is to be viewed as an indicator of the shift in demand for the period and not as a measure of the effectiveness of the EEOC or of any specific govermental activity. If in the future the pattern of demand changed due, say, to court rulings reducing the efficacy of the affirmative action effort, a more camplex variable would be required.

RED, the ratio of the median years of schooling of nonwhite workers to the median years of schooling of white workers, entered to control for the increased educational attainment of nowhite relative to white workers. Because this variable has a very strong trend, however, its effect cannot be readily distinguished from the trend. It is entered only in a limited number of equations.

In all cases the EEO variable obtains a statistically significant sizeable sign. A simple post-1964 time trend would, it is important to note, do about as well. The calculations do not "prove" any policy effect but they do show a change in pattern in the period of time unexplained by other factors.

The data in Tables 2 and 3 should not be taken as measures of extant discrimination in the U.S. labor market, as they do not control for various earnings-related characteristics which may differ between ethic groups. If one performs a multiple regression of the (logarithm) of earnings on various characteristics one obtains a crude indicator of overall differences in pay due to race, other factors held fixed (I use the word crude because of the lack of very fine measures of characteristics in standard data sets). Such calculations for 1978 show relatively modest difference in the pay of blacks and whites with both men and women included in the data set, even with very limited controls (see Table 4). 
TABLE 3

Regression Coefficients and Standard Errors for the Effect of Variables on the Log of the Ratio of Nonwhite to White Earnings and Docupational Position, 1948-1975

Measure of Relative Econamic Position

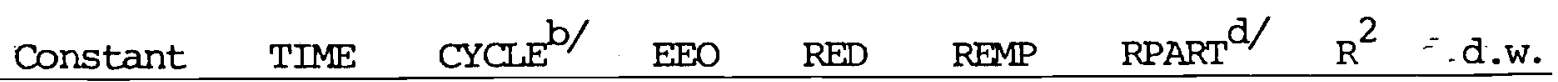
Male Workers

\begin{tabular}{|c|c|c|c|c|c|c|}
\hline $\begin{array}{l}\text { 1. Median Wages \& } \\
\text { Salaries, 1948-1975 }\end{array}$ & -.55 & $\begin{array}{l}-.001 \\
(.002)\end{array}$ & $\begin{array}{l}.42 \\
(.23)\end{array}$ & $\begin{array}{l}.08 \\
(.01)\end{array}$ & .83 & 2.32 \\
\hline $\begin{array}{l}\text { 2. Median Wages \& } \\
\text { Salaries of Year- } \\
\text { Round \& Full-Time } \\
\text { Workers, 1955-1975 }\end{array}$ & -.49 & $\begin{array}{l}.003 \\
(.002)\end{array}$ & $\begin{array}{l}-.40 \\
(.17)\end{array}$ & $\begin{array}{l}.03 \\
(.01)\end{array}$ & .87 & 2.19 \\
\hline $\begin{array}{l}\text { 3. Occupation } \\
\text { Index, 1958-1975 }\end{array}$ & -.33 & $\begin{array}{l}.003 \\
(.002)\end{array}$ & $\begin{array}{l}.10 \\
(.05)\end{array}$ & $\begin{array}{ll}.02 & .08 \\
(.004) & (.14)\end{array}$ & .99 & 2.31 \\
\hline Female Workers & & & & & & \\
\hline $\begin{array}{l}\text { 1. Median Wages \& } \\
\text { Salaries, 1948-1975 }\end{array}$ & -.96 & $\begin{array}{l}.022 \\
(.002)\end{array}$ & .34 & $\begin{array}{l}.13 \\
(.02)\end{array}$ & .97 & 1.85 \\
\hline $\begin{array}{l}\text { 2. Median Wages \& } \\
\text { Salaries of Year- } \\
\text { Round \& Full-Time } \\
\text { Workers, 1955-1975 }\end{array}$ & -.70 & $(.019$ & $\begin{array}{l}-.48 \\
(.27)\end{array}$ & $\begin{array}{l}.05 \\
(.02)\end{array}$ & .96 & 1.30 \\
\hline $\begin{array}{l}\text { 3. Occupation } \\
\text { Index, 1958-1975 }\end{array}$ & -.97 & $\begin{array}{l}-.001 \\
(.005)\end{array}$ & $\begin{array}{l}.12 \\
(.10)\end{array}$ & $\begin{array}{ll}.07 & .66 \\
(.01) & (.25)\end{array}$ & $.99+$ & 2.03 \\
\hline
\end{tabular}

a/ Dependent variables are the $\log$ of the relative economic status of nomwites to whites.

$\mathrm{b} /$ CYCLE obtained as residual from regression: $\mathrm{GNP}=6.14+.035 \mathrm{~T} ; \mathrm{R}^{2}=.99$ where $\mathrm{GNP}=\log$ of GNP in 1972 dollars. $(.001)$

Source: R. Freeman in Sherwin Rosen, ed., Studies in Labor Markets (University of Chicago Press: 1981). 
TABLE 4

Impact of Being Norwhite on the Log of

Average Hourly Earnings for Employed Private Sector Non-Agricultural Wage \& Salary Workers, May 1978

$\begin{array}{lcc} & \begin{array}{l}\text { Regression } \\ \text { Coefficient }\end{array} & \text { t Statistic } \\ \text { Constant } & .555 & -- \\ \text { Nonwhite } & -.069 & 8.32 \\ \text { Education } & .070 & 71.35 \\ \text { Female } & -.415 & 82.89 \\ \text { Experience } & & 69.22 \\ \text { (age - schooling - 6) } & .038 & 54.73 \\ \text { Experience squared } & -.00064 & .351 \\ \mathrm{R}^{2} & -- & \\ \mathrm{n}=35,816 & & \end{array}$

Source: Tabulated from May Current Population Survey Tapes 
At the same time that there has been a marked movement toward equality of earnings between employed blacks and whites, however, there has been a distressing deterioration in the likelihood of blacks holding jobs, particularly among the young. In 1964 the black male civilian employment/population ratio stood at . 73 ; in 1969, it was . 73; in 1979 it was .64. By contrast, for white males, the ratio went from .78 (1964) to .78 (1969) to .75 (1979). Equally striking, the youth joblessness problem of the decade was one of increasing relative worsening in the black youth position, for reasons that no one has yet satisfactorily explained. "/ The aggregate data thus tell two stories: improvement for the employed but a reduction in the overall employment rate, especially in the 1970s. Thus far, we have presented evidence on employer behavior and aggregative labor market performance. What about perceptions of discrimination (or reverse discrimination) by labor market participants? If, in fact, labor market discrimination has become less of a problem in the U.S. in recent years, one might expect to find only a moderate proportion of blacks reporting discrimination and to find that proportion declining over time.

Table 5 summarizes evidence on perceived discrimination from a variety of surveys. While there are differences among the surveys, there does appear to be a downward trend among blacks in reported discrimination $(17 \%(1969-70)$ to $14 \%$ (1977) in the Michigan PSID: 5.98 (1971) to $5.0 \%$ (1976) in the National Longitudinal Survey) with at most $15 \%$ of blacks reporting racial discrimination at work by the late 1970s. Again, we lack historical comparative data, but I think it is reasonable to believe that three or four decades ago one would have obtained much higher rates of reported discrimination.

In sum, the various pieces of evidence suggest a substantial reduction in labor market discrimination by race in the U.S. and rather striking differences vis-a-vis the U.K. While discriminatory differences may not have disappeared, they have become of sufficiently reduced magnitude as to lcad one important analyst (William Wilson) to make "the declinina sianificance of race" the title of his recent book. 


\section{TABLE 5}

Wage and Salary Workers Who Rcport Racial Discrimination at Work on National Surveys

Survey

Michigan Survey Research Center Surveys of Working Conditions/ Quality of Employment

$$
\begin{aligned}
& 1969-70 \\
& 1972-73 \\
& 1977
\end{aligned}
$$

National Longitudinal Survey
Men, 1971
1976
Women, 1972
Young Women, 1972
Young Men, 1971

\& Reporting Race Discrimination

Nonwhites

Whites

17.0

14.6

14.9

1.3

2.4

5.3

,

$\begin{array}{rr}5.9 & 0.9 \\ 5.0 & 1.4 \\ 6.0 & 0.9 \\ 8.3 & 0.8 \\ 11.4 & 1.4\end{array}$

Source: Tabulated from the relevant surveys. 
Role of Public Policy

To what extent can the changes in the economic position of black Americans and the apparent absence of employer discrimination in some aspects of market behavior be attributed to public policy designed to eliminate overt market discrimination?

This is a highly controversial question, as it raises important political and ethical issues in a society dedicated to equality of opportunity but not of outcomes. Some (Freeman, Brown, Leonard, Burstein) have concluded that public policy in the form of anti-discriminatory regulations have had an impact on the economic position of minorities; others (Butler \& Heckman) have expressed more skeptical views. Figure 1 provides a capsule picture of the major regulations and laws in question. In terms of actual pressures on companies to engage in nondiscriminatory employment practices, the main thrust of the law is in the form of "affirmative action" requirements under E.O. 11246 and of court suits and consequent judicial decisions with respect to charges of discriminatory acts. Most large companies in the U.S. have sufficient dealings with the federal government to be liable to affirmative action regulations. Indeed, the companies in the Newman study were, as noted, taken from the master list of the OFCC. As a result of affirmative action and antibias laws the personnel practices of U.S. companies are quite sensitive to issues of equal treatment of workers by race (see Table 6). Indeed, one of the major complaints about the affirmative action requirements placed on federal contractors is the expense it places on companies. While it is difficult to measure the "full cost" of the affimative action to the company, estimates of the direct administrative cost by accounting firms for the Business 


\section{FIGURE I}

$\underline{\text { Act }}$

Civil Rights Act of 1964 Title VII

Executive Order 11246

State and Local Statutes
What It Does

Prohibits discrimination on the basis of race, color, national origin, sex or religion. Enforced by Equal Employment Opportunity Commission (EFOC). Procedural mechanism is change-oriented. In 1975 EEOC spent $\$ 55$ million and handled 77,000 cases.

Prohibits discrimination by contractors doing business with federal government. Enforced by Office of Federal Contract Compliance in Department of Labor. Affinmative Action (AA) plans heart of program. AAP requires employers to analyze racial/sexual composition of work force, identify areas of underutilization and project goals and time tables for correcting problems.

Many states have Fair Employment Practice laws much like Title VII and agencies to administer the laws. The EEO defers to State agencies. In 1975 about \$34 million was spent by the agencies or about $60 \%$ as much as by the EEOC. 
Table 6: Evidence of Changes in Personnel Practices Due to Equal Employment Opportunity

$\boldsymbol{z}$ of companies

86

1. Have Formal EEO Prozram

96

Including Affirmative Action Plan

(of those subject to OFCCP regulations)

2. Have had investigation or other action under Title VII

63

3. Changes in selection procedures for EEOC reasors: 60

testing $p=o c e d u r e s$

revised job qualifications

31

application forms

20

rezrulting techniques

29

4. Special recruiting programs

for all minority workers

69

for minorities in proressional/managerlal positions

5. Prograns to insure EEO policies are implemented

communications on EEO policy

95

follow-up personnel or EEO office $\quad \therefore \quad 85$

training sessions on EEO $\quad \cdot \quad 67$

perlodic publications of EEO results. 48

EEO achievements included in performance appraisals 33

6. Speclal training programs

For entry-level jobs

For upgrading

For manazement positions

Source: Bureau of National Affairs Personnel Pollcies Forum Equal Emoloyment Ooportunity: Programs \& Results PPF Survey io. 112, Narch 1976

Iine 1,2 table 9 , p. 15

Ilne 3, table 3, p. 4

IIne 4, table 1, p. 2

line 5 , table 6, P. 9

line 6 , tabie 5, p. 8 
Roundtable suggests magnitudes on the order of $\$ 78$ per employee per year, or roughly 18 of profits. $9 /$ As any observer of American corporations can attest, there is a significant effort being made by most companies to comply with (or, more cynically, to appear to comply with) affimative action requirements.

In the American legalistic society court decisions necessarily play a major role in the actual impact of EEO legislation. Between 1964 and 1981 more than 5000 suits dealing with discrimination under title VII were decided in the Federal District Courts. ${ }^{10 /}$ Nearly a third of these were class action suits, in which statistical evidence pertaining to disparities have come to play a significant role in deciding guilt or innocence.

A class action discrimination suit has a major impact on company behavior. In cases with which I am familiar companies invariably show an improvement in their treatment of minorities after the first major suit of this nature. The suit requires them to examine longstanding personnel practices which, possibly inadvertently, have limited the employment prospects of minorities within firms. It is also noteworthy that companies invariably seek to limit statistical analyses to their performance after July 1, 1965 (when the 1964 Civil Rights Act took effect), since the data invariably shows marked improvements after the effective date of the law.' Before July, 1965, discrimination on the basis of race, sex, and so forth was legal under federal law, though not under some state laws.

In the late 1960s court decisions regarding discrimination seemed relatively favorable to plaintiffs. As the most egregious forms of discrimination have disappeared, however, the likelihood of plaintiffs winning discrimination suits has fallen. Table 7 documents this claim for discrimination suits in 5 circuit courts from 1966-69 to 1980, using data from Richard Lung's analysis of 314 cases in the courts from 1966 to 1980. The table shows a striking increase in the proportion of judgements for the defense, from 148 in the former period to 518 in the latter, though no 
Table 7: Percentage Distribution of Court Discrimination Suits, 1966-69 and 1980

Result (Metric for computing average score)

$$
\begin{gathered}
1966-69 \\
(n-22)
\end{gathered}
$$

$\%$

27

47

9

9

14

65.6

Average Score

Judgement for defense, case dismissed (0)

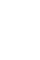

1980
$(n=35)$

\%

26

11

6

6

51

39.5

Source: Richard E. Lung

"A statistical Analysis of Title VII, Employment Discrimination Court Cases," thesis, Harvard University, April, 1982.

See p. 7 for coding used by Lung; pp. 15-20 for data. 
decrease in the fraction of cases in which plaintiffs won relief. Scoring the outcames on a range from 0 to 100 , with 0 least favorable to the plaintiff and 100 most favorable, the average discrimination suit in the 5 major circuit courts scored 65.6 in 1967-69 compared to 35.9 in 1980 . In a statistical regression, with numerous controls for the type of suits, Lung obtained a significant downward trend in the extent of plaintiff's victory comparable to the change in mean figures cited above. Over the period covered, there was a one-half standard deviation shift in the outcomes, against plaintiffs ${ }^{11 /}$ which Lung attributed to the striking change in the nature of suits being brought, from those involving blatant discrimination to more subtle forms. As an example of an early court of appeals case, Lung cites Gillin vs. Federal Paper Board, 479F 2d 100 where the judgement noted

\footnotetext{
- He advised Gillin when she expressed her interest in the position that it was not suited to a women and was more suitable to a man. He indicated to the EEOC investigator that he would have placed the job newspaper advertisement in a column specifically directed to males, had such been available. On trial while he conceded that a women might handle the job under special circumstances, he adhered to the view that the traffic manager's position was a "man's" post. He stated that "(i)t would be an extreme case that a woman could ever take on a truck fleet operation and do it properly." He further testified:

Q. So you are satisfied that Miss Gillin's femininity hurt her and also her qualifications weren't there, right?

A. Correct

Q. All right. And that had her qualifications has been there her femininity still would have hurt her?

A. Yes, it might have.'
} 
One does not find such overt practices in the court cases of the 1980s.

Economic Studies of the Effectiveness of Affirmative Action and Court Activities

Two types of evidence have been offered with respect to the impact of the legal anti-bias effort on the gains of blacks shown earlier: time series data, focusing on the timing of the observed changes (see figure 1); and time series/cross-section comparisons of the performance of sectors of the economy/firms more or less pressured by the law.

With respect to the time series, while alternative possibilities have been suggested to explain the post-1964 upward trend in the position of blacks, the impact of antibias laws and regulations remains the most plausible explanation. Efforts to relate the trend to changes in attitudes ( Burstein ), in black labor force participation (Butler \& Heckman) have not eliminated the post-1964 shift shown in Figure 2 (see Brown, Freeman). This does not, of course, imply that the time series provides strong evidence that public policy was effective, only that it is consistent with such an explanation.

A complementary potentially more insightful mode of examining the impact of public policy is to contrast the performance of companies/sectors of the econamy with/without affinmative action regulations or government compliance pressures and with/without significant court suits. Several studies were conducted in the early 1970s examining the apparent impact of the affinnative action contract compliance effort on company performance (Buman, Ashenfelter-Heckman, Heckman-Wolpin, Goldstein-Smith). Three of 
the four studies found evidence that black employment increased more rapidly in companies facing severe federal pressure than in other companies. One did not find such effects. These studies, however, dealt with OFCC activity at an early stage in its history, before major administrative changes were made. Since the early studies absence of publicly available data has precluded further work in the area until recently.

The impact of court decisions and suits on company performance, while extremely important in the eyes of those who have witnessed first-hand the effect of suits on behavior, has also not received the statistical study it merits until very recently.

Both gaps in our knowledge of the apparent role of public policy on the observed changes in black labor market position have been remedied by a recent doctorate thesis at Harvard University (Jonathan Leonard, Ph.D. dissertation, 1982). This dissertation provides what is perhaps our best statistical answer to questions regarding the impact of the two main thrusts of the law -- court suits and affirmative action.

\section{The Leonard Dissertation Results}

Leonard's dissertation tests separately for the effect of court suits and affirmative action pressures on growth of employment of minorities, identifying the impact of policy effects on employment by linking policy in a period of time to growth in employment over time.

Table 8 summarizes the results of Leonard's analysis of the effect of class action suits per nonwhite worker on minority employment. Leonard's "experiment" is to relate the 1978 proportion of workers in a state-2 digit (Standard Industrial Classification) industry cell who are black to the 1966-1978 cumulated number of equal employment opportunity suits per firm in that cell, to the proportion of blacks in the cell in 1966, and to various 
control variables. To perform this analysis he coded over 1,000 cases by industry and state; his data set contains 555 observations. If court cases have an impact on employment of minority workers one would expect a positive coefficient on the case variable, and this is what he finds.

Columns 1 and 2 of the table record the proportion of blacks in 1966 and 1978, while column 3 gives the change in proportion, which are always positive, in part due to the rising black share of the U.S. population. Note, however, the markedly larger percentage increase in the proportion black in the white collar and professional-managerial occupations than in the blue oollar occupations.

The positive significant coefficients on the court case variable in colum 4 indicate that the growth of the black proportion of workers was not random across cells, but rather was largest where there was more court activity. The regression coefficients in column 5 show that a one standard deviation change in the number of suits per nonwhite worker raised the black proportion of workers in a state-industry cell from .09 to .25 standard deviations, depending on the specific proportion under consideration. The greatest effects were found for the more skilled male occupations and for black females in nearly all occupations.

From these calculations Leonard concludes that FEO suits have an impact on the employment practices of American industry.

This does not, of course, mean that large numbers of black workers have been involved in court suits. They have not. What appears to be the case is that companies "get their act together" in various areas of minority employment following a suit. 


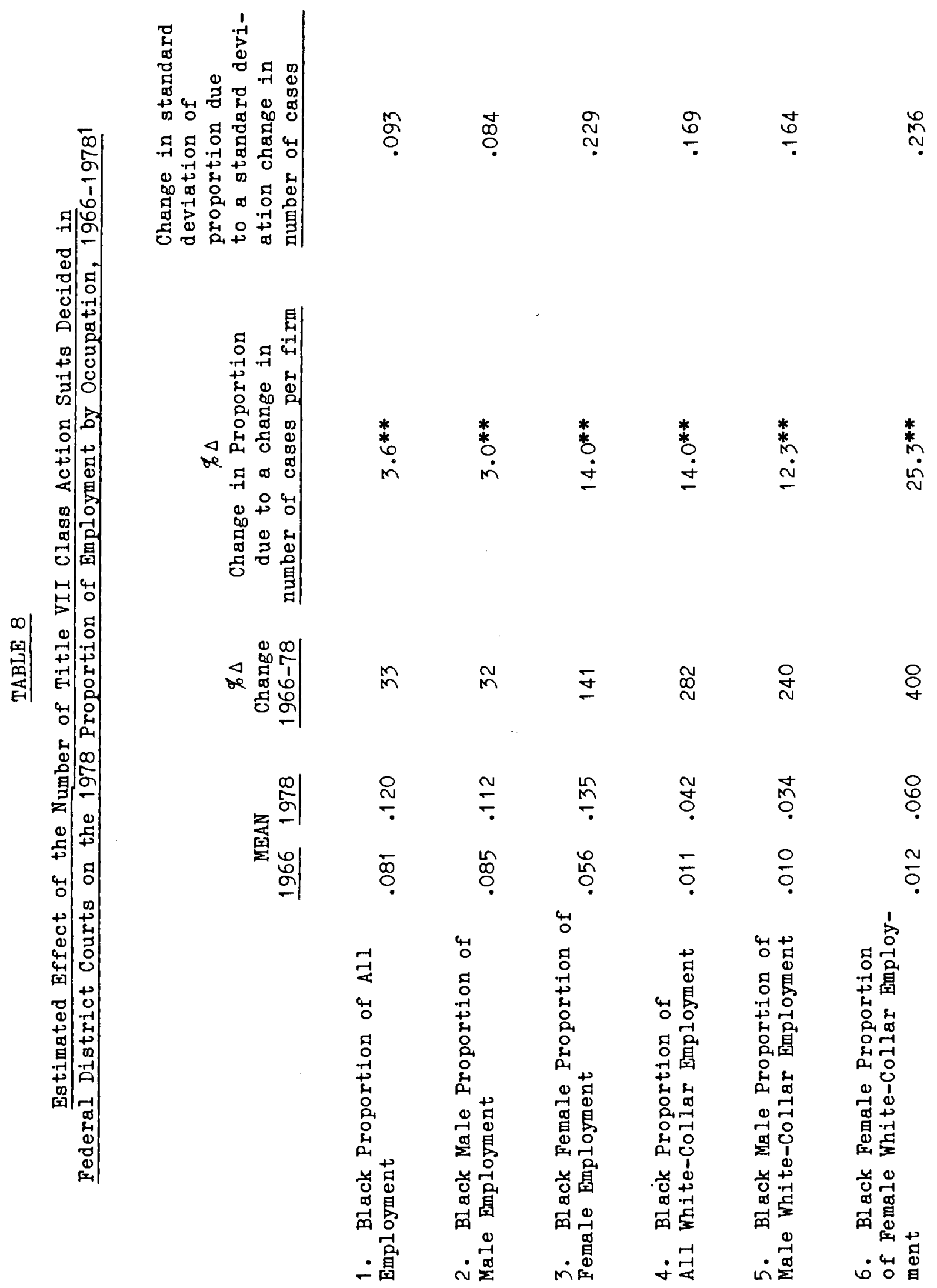




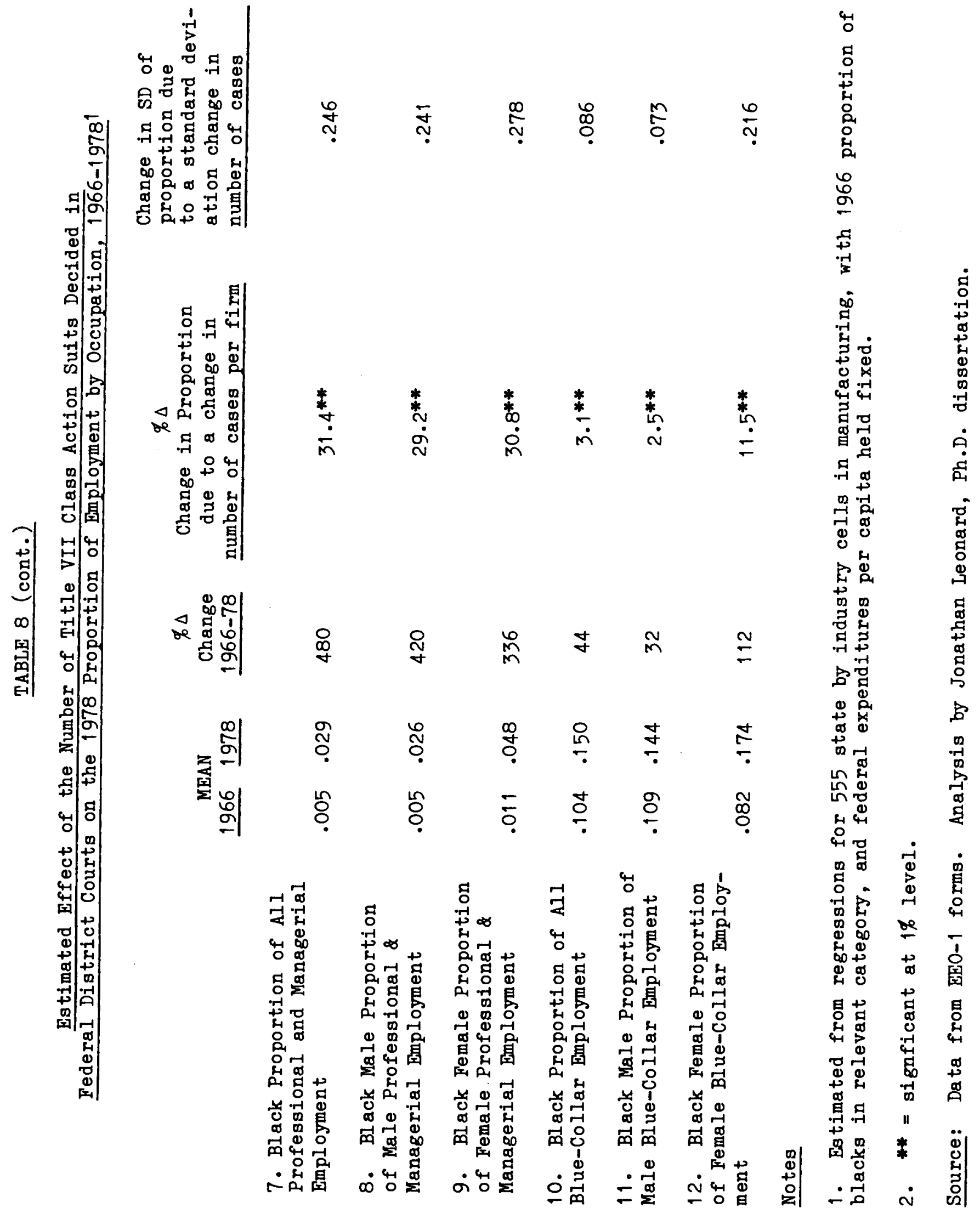


Turning to the impact of affinmative action, Leonard has obtained information on the black share of employment in 18,000 establishments, $72 \%$ of whom are federal contractors required to have affimative action plans and $28 \%$ of whom are noncontracting establishments, for the period 1974-1980. In addition, he has information on the number of 'compliance reviews' (formal examination of the effort to comply with affimative action plans by federal compliance officials). To evaluate the impact of affirmative action on establishment employment of black workers he calculates the percentage changes in the black proportion of workers in contractor and noncontractor establishments from 1974 to 1980 and the percentage changes in the black proportion of workers in reviewed and nonreviewed contractor establishments over the same period. If the affirmative action effort was significant one would expect greater increases in the black share of employment in contractor than in noncontractor establishments and greater increases in the black share of employment in reviewed than in nonreviewed establishments.

Table 9 presents Leonard's preliminary findings for black workers en toto and in professional and managerial occupations, and for black male workers en toto and in those occupations. Panel A treats establishments by contractor status while panel B treats ontractor establishments by review status.

The figures in panel A show uniformly larger (and statistically significant given the sample sizes) increases in the black share of workers in contractor than in noncontractor establishments. The differentials are moderate but noticeable for all employees but quite large in the professional and managerial areas, which have attracted much affinmative action pressure due to low "utilization" of minorities. The difference in the annual rates of change given in the final column to the right suggest 
that the relative demand for black workers in contractor firms grew by $1-3 \%$ per year more rapidly than in noncontractor firms (depending on the particular group).

The data in panel B suggest that much of the "better" performance of federal contractors is a result of compliance reviews. In all of the cases, contractors who were reviewed show greater percentage increases in the black proportion of employees than do contractors who were not reviewed. Unfortunately because of differences in the samples drawn, however, it is not possible at this time to contrast the reviewed/notreviewed establishments with non-contractor establishments: as can be seen in the table, the proportions in panels A and B are not consistent; when Leonard completes a full analysis of all establishments, we will have a better picture of behavior. As it stands, however, the panel B data strongly suggest that contractor finms respond to pressures generated by a review of their affirmative action plans, with relative demand for black labor rising by $1-5 \%$ per annum as a result of the reviews.

In addition to looking at the growth in the black share of employment Leonard has also compared the black share of new hires and promotions with the share of employment, on the hypothesis that hires and promotions represent the firms' margin of adjustment. In 1978 his data show that whereas (in companies facing compliance reviews) 1.68 of professionals were black men, $3.2 \%$ of new hires into professional jobs were black, and $2 \frac{3}{2} \%$ of promotions among professionals were given to black men -- a rate 568 above their share of the stock of workers. Similar patterns are observed for other white collar occupations but not necessarily for blue collar jobs where blacks are relatively well represented. ${ }^{12 /}$ 
TABLE 9

The Changing Percentage of Workers Who Are Black in Establishments, by Affirmative Action Status and Pressure, 1974-1980

A. By Contractor Status ${ }^{a}$

Occupation/Demographic
Group

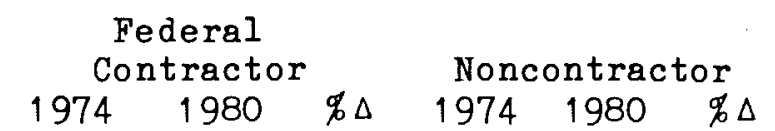

Difference in Compound Annual $1974 \quad 1980$ \% $1974 \quad 1980 \quad \% \Delta$ Growth

1. All Occupations

$\begin{array}{llllllll}\text { Both sexes } & .088 & .107 & 22 & .092 & .107 & 16 & 0.8 \\ \text { Male Employees } & .083 & .098 & 18 & .091 & .104 & 14 & 0.7\end{array}$

2. Professionals

$\begin{array}{llllllll}\text { Both sexes } & .020 & .035 & 75 & .022 & .034 & 55 & 2.0 \\ \text { Male Employees } b & .017 & .025 & 47 & .018 & .022 & 22 & 3.2\end{array}$

3. Managers

\begin{tabular}{|c|c|c|c|c|c|c|c|}
\hline Both sexes & .025 & .043 & 72 & .032 & .048 & 50 & 2.3 \\
\hline Male Employees & .024 & .038 & 58 & .026 & .039 & 50 & \\
\hline
\end{tabular}

B. Compliance Review in $1978^{c}$

4. All Occupations

$\begin{array}{llllllll}\text { Both sexes } & .106 & .129 & 22 & .084 & .097 & 15 & 1.0 \\ \text { Male Employees b } & .095 & .112 & 18 & .081 & .090 & 11 & 1.0\end{array}$

5. Professionals

$\begin{array}{llllllll}\text { Both sexes } & .015 & .032 & 113 & .020 & .053 & 65 & 4.0 \\ \text { Male Employees b } & .013 & .024 & 85 & .017 & .024 & 41 & 4.6\end{array}$

6. Managers

$\begin{array}{llllllll}\text { Both sexes } & .022 & .043 & 95 & .019 & .031 & 63 & 3.0 \\ \text { Male Employees }{ }^{b} & .022 & .039 & 77 & .018 & .028 & 56 & 2.1\end{array}$


TABLE 8 (cont.)

Source: Tabulated from Office of Federal Contract Compliance computer tapes by Jonathan Le onard.

a) Sample size: 12918 federal contractor establishments 5082 non-contractor establishments

b) Figures report percentage of men who are black.

c) Sample size: 272 reviewed establishments 2073 never-reviewed establishments 
In short, the Leonard dissertation results suggest that both court suits under Title VII and affirmative action under Executive Order 11246 contribute to employment of minorities.

From micro employment studies to macro earnings patterns

The reader will notice that Leonard's (and earlier studies) of the effect of policy on black economic progress analyze employment whereas the aggregative data show improvements in earnings and occupational status. One way of relating the two pieces of evidence is to treat the micro changes in employment as representing the effect of shifts in demand, which given relatively fixed supplies of black labor, cause increase in black wages. From this perspective the key link between the micro-analysis and the macro earnings patterns is found in the elasticity of demand for black labor: the less elastic is the demand curve, the greater will be the impact of any shift in demand on the relative wages of black workers.

As a first approximation, let us develop a simple two sector model to analyze the potential impact of the observed 1-2\% annual increase in the black share of employment in companies with affirmative action plans. This model, contained in Appendix A, relates the growth of the wages of black workers relative to white workers to the growth of employment in the contractor sector on the assumption that the sector must increase wages to attract additional workers. On the assumption that the relative supply of black and white workers does not change, the model yielded the following equation for the relative wages of black workers:

Percentage Change in Relative Wages = of Black Workers

Contractor Share, Elasticity of Demand for of Employment
Percentage Growth in Demand for Black Workers Relative to White Workers in Noncontractor Sector Black Relative to White Workers
(Differential Growth of Relative to White Workers in the contractor Sector Versus the Noncontractor Sector 
According to this equation the observed growth of relative employment in the contractor sector of 1-38 per annum will raise the wage of blacks by the ratio of the contractor share of employment to the elasticity of demand for black as opposed to white workers. Assuming for simplicity that demand elasticity is unity and that the contractor share is .60 , we see that every 18 increase in relative employment in the contractor sector will raise demand by .68 . Over the six years covered, a 1-38 annual increase in relative employment due to affirmative actionpressures would translate into a 4-118 increase in the ratio of black to white wages-a magnitude consistent with affirmative action paying a major role in improving the ratio of black to white earnings in the economy. As Leonard's estimates of the growth of the black share of employment in companies facing affirmative action pressure are comparable to those found in three of four earlier studies (AshenfelterHeckman; Heckman-Wolpin; Burman; the exception being Goldstein and Smith) it seems reasonable to conclude that the micro-establishment work is consistent with an explanation of black economic progress that puts great weight on public policy.

Conclusion

This paper began with a comparison of the employment practices of American and British fims with respect to ethnic/national groups. It found American firms to be roughly color-blind; it then went on to document what is by now the widely accepted finding regarding the diminished significance of race in the U.S. labor market. With respect to the highly controversial issue of the impact of public policy, the paper summarized the newest research in the area, which finds a sizeable role for court suits and for affimmative action compliance activity. While U.S. public policy in the area of equal employment has its faults, particularly with respect to administrative paper work, it has apparently done what it was meant to do: substantially remove employer discriminatory barriers to minority economic progress. 
Footnotes

1/ The compensating differential theory of market discrimination was first developed by G. Becker. For further theoretical work see K. Arrow, R. Freeman.

2) The Firth study sent seven letters to 282 employers advertising in the press for accountants and financial executives. The Newman study sent two letters to 207 companies on the OFCC list. The difference in the acceptance rates represents the difference between letters sent to employers with a definite vacancy and those without.

3/ See Industrial and Labor Relations Review, Cormunications, Vol. 33, No. 4, July 1980, pp. 543-9.

4/ Recall that prior to July, 1965 companies could indeed discriminate blatantly without breaking federal law.

5/ That black earnings and occupational position tend to be procycles has been found in numerous studies. See, for example, R. Freeman, "The Changing Labor Market for Black Americans, 1948-1973" (Brookings Papers on Economic Activity, Sumer 1973). 6/ See R. Freeman, "Have Black Labor Market Gains Post-1964 Been Permanent or Transitory?" National Bureau of Economic Research, Working Paper No. 751, September, 1981.

7/ The employment/population rates for black youths aged 18-19 fell from 52 in 1964 to 37 in 1977 while the ratio for ite youths actually rose from 58 to 65 over the same period. (See R. Freemanand D. Wise, The Youth Labor Market Problem: Its Nature, Causes and Conseguences, University of Chicago Press, 1982). 8/ William Wilson, The Declining Significance of Race (University of Chicago, 1978). 
Footnotes (cont.)

9/ Arthur Anderson, "Business Roundtable Study of Costs of Regulation." 10/ This figure was tabulated from the LEXIS computer file of court cases. District courts handle only a selected set of cases. While their case load is not random, there is no reason to expect it to bias our results, as the nonrandom component has nothing to do with our analysis. 11) See Richard Lung, "A Statistical Analysis of Title VII Employment Discrimination Court Cases."

12) See Leonard, Table 3-1 from seminar at Harvard University labor workshop, April 1982. 
Appendix A: Formal Model Relating the

Shift in the Black Share of

Employment to Macro Changes in Wages

Let: $\quad \dot{\mathrm{E}}_{1}=$ percentage change in the black share of employment in the contractor sector of the economy

$\dot{\mathrm{E}}_{2}=$ percentage change in the black share of employment in the noncontractor sector

$\dot{\mathrm{x}}_{1}=$ percentage growth in demand for black share of workers in noncontractor sector of the economy

$n$ = elasticity of demand for black share of workers, assumed the same in both sectors

$\dot{\mathrm{W}}=$ percentage change in wages of black workers relative to other workers, assumed the same in both sectors.

Then, the change in demand for black workers in the economy as

a whole is:

$$
\begin{aligned}
\dot{\mathrm{E}}_{1}+(1-\alpha) \dot{\mathrm{E}}_{2} & \left.=\alpha\left(\dot{\mathrm{x}}_{1}-\eta \dot{\mathrm{W}}\right)+(1-\alpha) \dot{\mathrm{x}}_{2}-\dot{n \hat{W}}\right) \\
& =\dot{\mathrm{x}}_{2}+\alpha\left(\dot{\mathrm{x}}_{1}-\dot{\mathrm{x}}_{2}\right)-\dot{n \dot{W}}
\end{aligned}
$$

where $\alpha=$ "share" of employment in contractor sector.

Setting the change in demand equal to the assumed zero change in supply yields the following equation for wage changes:

$$
\dot{\mathrm{w}}=\frac{\dot{\mathrm{x}}_{2}+\alpha\left(\dot{\mathrm{x}}_{1}-\dot{\mathrm{x}}_{2}\right)}{\eta}
$$

But, given the same elasticity of demand in the two sectors, the relative employment will grow more in the contractor sector according to the equation

$$
\dot{\mathrm{E}}_{1}-\dot{\mathrm{E}}_{2}=\dot{\mathrm{x}}_{1}-\dot{\mathrm{x}}_{2}
$$

i.e. only if the shift in demand is greater in the contractor sector.

Substituting (3) into (2) yields:

(4) $\dot{\mathrm{w}}=\frac{\dot{\mathrm{x}}_{2}+\alpha\left(\dot{\mathrm{E}}_{1}-\dot{\mathrm{E}}_{2}\right)}{\eta}$, the equation given in the text. 


\section{Bibliography}

Arrow, Kenneth J. "The Theory of Discrimination," in Orley Ashenfelter and Albert Rees, eds., Discrimination in Labor Markets (Princeton, NJ, 1973).

Ashenfelter, Orley and James J. Heckman. "Measuring the Effect of an Anti-discrimination Program" in Evaluating the Labor Market Effects of Social Programs, eds. Orley Ashenfelter and James Blum. (Princeton, NJ: Industrial Relations Section, Princeton University, 1976). Becker, Gary S. The Ecomomics of Discrimination, second edition. (Chicago, II, 1971).

Brown, Charles. "The Federal Attack on Labor Market Discrimination: The Mouse That Roared?" NBER Working Paper No. 669, May, 1981.

Burman, George. "The Economics of Discrimination: The Impact of Public Policy". Ph.D. Thesis, University of Chicago, 1973.

Burstein, P. "Equal Employment Opportunity Legislation and the Income of Women and Nonwhites," unpublished paper, Yale University, August, 1978. Butler, R. and J. Heckman. "Government's Impact on the Labor Market Status of Black Americans: A Critical Review," Industrial Relations Research Association, Equal Rights and Industrial Relations (Wisconsin, 1977) pp. 235-281.

Freeman, R. "The Changing Labor Market for Black Americans," Brookings Papers on Economic Activity, 1973. - "Labor Market Discrimination: Analysis, Findings and Problems".

Chapter 9 of Frontiers of Quantitative Economics (M. Intriligator and D. Kendrick, eds). Amersterdam: North-Holland Publishing Company, 1974. - "Have Black Labor Market Gains Post-1964 Been Permanent or Transitory?" National Bureau of Economic Research, Working Paper No. 751 , September, 1981. 
\& David Wise. The Youth Labor Market Problem: Its Nature, Causes, and Consequences. University of Chicago Press, 1982.

Firth, Michael. "Racial Discrimination in the British Labor Market", Industrial \& Labor Relations Review. Vol. 34, No. 2 (January 1981): $265-72$.

Goldstein, Morris and Robert S. Smith. "The Estimated Impact of the Anti-Discrimination Program Aimed at Federal Contractors", Industrial and Labor Relations Review 29 (July, 1976): 523-543.

Heckman, James J. and Kenneth Wolpin. "Does the Contract Compliance Program Work? An Analysis of Chicago Data," Industrial and Labor Relations Review 29 (July 1976): 544-564.

Leonard, Jonathan S. "Does Affimative Action Work?" unpublished paper, Harvard University, April 1982.

Lung, Richard. "A Statistical Analysis of Title VII Employment Discrimination court Cases."

Newman, Jerry M. "Discrimination and Recruitment: An Empirical Analysis", Industrial \& Labor Relations Review. Vol. 23, No. 1 (October 1978): 15-23. Wilson, William. The Declining Significance of Race. University of Chicago, 1978. 